Open Access

\title{
Erratum to: Nutritional vitamin D supplementation and health-related outcomes in hemodialysis patients: a protocol for a systematic review and meta-analysis
}

Anita Mehrotra*, Wai-Yin Leung and Tannia Joson

\section{Erratum}

Unfortunately, the original version of this article [1] published with an incorrect citation. The citation has now been updated to 4:115, which is the correct citation for the article. The Publisher apologizes for any inconvenience caused.

Published online: 11 August 2015

\section{Reference}

1. Mehrotra A, Leung W, Joson T. Nutritional vitamin D supplementation and

health-related outcomes in hemodialysis patients: a protocol for a

systematic review and meta-analysis. Systematic Reviews. 2015;4:115.

* Correspondence: Anita.Mehrotra@mssm.edu

Division of Nephrology, Department of Medicine, Icahn School of Medicine at Mount Sinai, One Gustave L. Levy Place, Box 1243, New York 10029, NY, USA
Submit your next manuscript to BioMed Central and take full advantage of:

- Convenient online submission

- Thorough peer review

- No space constraints or color figure charges

- Immediate publication on acceptance

- Inclusion in PubMed, CAS, Scopus and Google Scholar

- Research which is freely available for redistribution

Submit your manuscript at www.biomedcentral.com/submit 